\title{
IMPLEMENTATION OF SYSTEM THEORY IN EDUCATIONAL MEDIA FOR EARLY MARRIAGE CASES IN YOGYAKARTA
}

\author{
Ainul Luthfia Al Firda \\ Mahasiswa Pascasarjana UIN Sunan Kalijaga Yogyakarta \\ ainulfrida@gmail.com
}

\begin{abstract}
Early marriage is an issue that is widely discussed around the world. Because the discourse of early marriage is often motivated by several factors that deviate from a child's justice rights. Even the issue of early marriage is also referred to as part of child abuse. The factors that cause early marriage are parents, economy, social and customary pressures, perpetuating relationships, social media and influencers, unwanted pregnancy, lack of reproductive health education for children and parents. PKBI is one of the institutions whose concentration focuses on the study of sexual and reproductive health for all parties providing several means to voice the importance of suppressing the increase in the rate of early marriage, especially in Yogyakarta. One of the efforts made by PKBI is to hold several discussion forums. The holding of discussions is one of the comprehensive efforts to educate adolescents and parents about the importance of sexual and reproductive health, which in turn can hamper the process of early marriage.
\end{abstract}

Keywords: Early Marriage, Reproductive Health Education, Early Marriage Factors, Communication

\section{INTRODUCTION}

Marriage is a fitrah that is recommended by all religions which aims to continue offspring. Marriage is also referred to as a bond that binds the outer and inner relationships of men and women to make them husband and wife. Marriage is also something that is important and sacred because a married couple will live a life together and it should be underlined that mental and physical readiness are the main foundations before taking a more serious path. The discourse about marriage is no longer an ordinary discourse because there are still many people who are hesitant to live it. However, early marriage is no longer a common problem, ironically at this time early marriage has become a trend for young people without any long-term considerations.

Nowadays, the age limit for marriage has become a debate for several circles, both practitioners and academics. Siti Fatimah explained in her research in the village of Sarimulya Boyolali about the phenomenon of high early marriages that 
occur due to lack of public education about marriage, economic problems, traditional factors and local people's parents. The same thing was also studied by Yekti Satriyandari and Fitria Siswi Utami that there was a cultural shift with the trend of early marriage and the issue of premarital pregnancy being commonplace. (Utami, 2019) This assumption is the same as Kemal in his presentation at the PKBI Webinar that the discourse of early marriage has become a trend due to the influence of social media, one of which is the voice of influencers who speak about the romance of early marriage.

The development of social media and the large number of influencers who carelessly and deliberately voice the romanticism of early marriage have triggered many new phenomena about early marriage which are considered normal. The phenomenon of early marriage should be a public concern, because if this practice is perpetuated, many negative impacts will appear. Starting from divorce, violence and even death are one of the most vulnerable impacts of the practice of early marriage.

UNICEF records explain that in 2016 around 700 million women in the world were married under the age of 15 years, while the 2014 BKKBN data explained that Indonesian teenagers married between the ages of 15-19 years and reached 74 million people with a percentage of 59\%. This phenomenon then placed Indonesia at 37 th place in the world in terms of early marriage in 2010. Based on this data collection, Indonesia is experiencing a very tense crisis and the practice of early marriage in Indonesia should be considered in various aspects of life, both domestic and public. Education related to reproductive health, family resilience and marriage issues is one way to optimize the emphasis on cases of early marriage and domestic violence.

PKBI Yogyakarta or Indonesian Family Planning Association is an institution that focuses on reproductive health issues. This institution is one of the institutions that often provides education related to issues related to reproductive health and sexual violence. Starting from holding exhibitions, discussions to training. These events cannot be separated from the mission of reproductive health education, one of which is the issue of early marriage.

On December 15, 2020 through the DIY Update event, PKBI Yogyakarta held a webinar with the theme Observing the Application of Adolescent Reproductive Health (KRR) in the Special Region of Yogyakarta. This discussion was also 
enlivened by the Yogyakarta Health Office, Yogyakarta BKKBN and Yogyakarta Education Office as well as National PKBI administrators. At this event, several presenters explained the causes and effects of early marriage. Therefore, this event becomes an important forum to voice the importance of emphasizing the practice of early marriage.

Small discussions like this are starting to be taken into account and noticed by several government and non-government parties in Yogyakarata because from the scope of these small discussions, education outside of school hours becomes meaningful for teenagers. Online discussion-based education is a form of concern for the nation's education. Tabah Listianto explained the importance of a technological approach in managing technology, which is an important component in the learning process. Media has an important role not only as a medium of entertainment, but also as a comprehensive learning media. Therefore, starting from small discussions that are carried out online or online, it becomes a solutive and appropriate learning tool.

Based on the above background, the researchers tried to understand by formulating problems such as how system theory is implemented in the case of early marriage and how effective online discussion education is in voicing reproductive health..

\section{RESEARCH METHODS}

The method used in this study is a qualitative research method by taking data based on the results of interviews and group discussion forums at a discussion event organized by PKBI Yogyakarta with the theme "Observing the Application of Adolescent Reproductive Health in DIY". The Focus Group Discussion or FGD technique is a data collection technique based on perceptions, opinions, beliefs, concepts and ideas. The purpose of FGD research is to explore issues related to specific topics of discussion. The importance of researching and further reviewing this discussion because the discussion media has an important role in voicing reproductive health education for adolescents, because providing education about reproductive health and matters related to early marriage from the start can reduce the increase in the number of cases of violence and the practice of early marriage. . 
Thus, the discussion becomes an intermediary media about the importance of reproductive health education for adolescents in Yogyakarta.

\section{DISCUSSION RESULT}

In dealing with several social cases, systems theory is one of the theories that has been used as an analytical knife for some PKBI volunteers in solving several cases. This is in line with the perspective of Pincus Minahan who explained that the social worker approach must focus on the existing system in his environment, especially his immediate environment. Theoretically, this Pincus Minahan approach emphasizes how a person maintains their social environment system with three help systems, namely: informal (natural system), formal group system, social system.

In this case, as an effort to deal with cases of early marriage, PKBI conducts socialization on reproductive health and provides recommendations to other institutions that care about adolescents so that active sex activities that will result in unwanted pregnancies (KTD) can be prevented. ${ }^{1}$ In every socialization carried out, PKBI explains that early marriage is a form of violation of children's rights. These rights include the right to education, the right to protection from all forms of physical and mental violence, the right to the highest attainable health, the right to freedom of expression, the right to rest and leisure time, the right not to be separated from parents, the right to protection from all forms of exploitation, as well as the right to survival and development. With this, PKBI invites young people who are also agents of change to talk about the rejection of child marriage, as well as provide education through creative ways by making a mural "Stop Child Marriage" and a theater performance. ${ }^{2}$

Nowadays, early marriage is often romanticized through broadcasts on social media, be it television or application-based media. These shows are performed by public figures who indirectly or directly provide education that early

${ }^{1}$ Antonius Jhe Saksono, "PKBI Mengurai Pergulatan Pernikahan Dini di Jawa Tengah", dalam https://pkbijateng.or.id/pkbi-mengurai-pergulatan-pernikahan-dini-dijateng/, accessed at 12 Januari 2021.

2Jessica Rachel, "Anak Muda Bicara Perkawinan Anak", https://pkbi.or.id/anakmuda-bicara-perkawinan-anak/, accessed at 12 Januari 2021. 
marriage is a trend that must be developed. The impact is that teenagers will understand that the phenomenon of early marriage is an interesting thing and sometimes marriage is also a shortcut to solving problems. In fact, several studies have explained that many cases of domestic violence stem from early marriage and a lack of readiness for marriage.

Rayi Lujeng explained in his research that economic unpreparedness in the household is often the trigger for the rise of cases of domestic violence. This he explained that someone had experienced domestic violence, they were a couple who had been married since the age of 15 and 17 years. In addition to economic problems, cases of domestic violence are also often caused by an unequal power relationship between husband and wife. ${ }^{3}$

Based on the above phenomenon, Kemal tries to explain further about the case of early marriage by using a systems theory approach. System theory is a certain relationship between the sub-systems with the system as a unit. This theory can be implemented in families, groups, communities, society. The concept is informal (including family, relatives, peers), formal (eg organizations, support groups), social systems (eg schools, hospitals) ${ }^{4}$. Here Kemal tries to map out an intervention plan using a SWOT analysis (Strengths, Weaknesses, Opportunities, Threats) in handling cases of early marriage in Yogyakarta.

First, Strengths or strength. In this case, the Yogyakarta area regarding services for adolescent health and health issues is quite good and even plural, so that the support provided from Yogyakarta health services for adolescents can be categorized as adequate and quite a lot. In connection with this, regarding adolescent health, services and education, all of these have been regulated in Perhub on Youth Health Yogyakarta 109 No. 15. In addition, there is a lot of support that focuses on sexual and reproductive health that comes from Non Government Organizations or NGOs that provide comprehensive services such as PKBI, UNALA YOUTH and so on.

\footnotetext{
${ }^{3}$ Rayi Lujeng dkk, "Kekerasan dalam Rumah Tangga pada Kasus Pernikahan Dini”, Jurnal Medula Unila, Vol 6, No 1, 2016, p. 147.

${ }^{4}$ Sugeng Puji Leksono and Mira Wuryantoro, "Implementasi Teori, Tekhnik, dan Prinsip Pekerjaan Sosial”, ( Malang: Intrans Publishing, 2019), hlm. 29
} 
Second, weaknesses or weaknesses. The weakness or dilemma experienced by many teenagers in Yogyakarta is the confusion of teenagers in conveying the problems they are experiencing. This means that there are still teenagers who are afraid, confused and even embarrassed to talk about the problems they are experiencing, such as mental health disorders, sexually transmitted diseases, sexual violence and so on. Meanwhile, many services related to adolescent problems have been provided in Yogyakarta. In addition, there is a lack of understanding of sexual and reproductive health.

Third, opportunities or opportunities. In this case, Kemal stated that the issue of sexual and reproductive health is still not comprehensive, meaning that this issue is mostly discussed only in certain communities. Then he quotes from Piere Bourdieu's theory of arena, habitus, capital and strategy. This theory talks about a social practice carried out by agents in a relationship between habitus, realm and capital. This theory relates to the application of digital media, especially social media through several platforms that help raise sexual and reproductive health issues through their posts or other activities.

Fourth, threaths or threats. The process of providing services and information will certainly not escape threats. The threat covers cultural areas where there is still an assumption that talking about sexual issues is considered taboo.

Based on the explanation above, the things that PKBI is trying to do as expressed by Kemal in an effort to implement adolescent reproductive health in Yogyakarta using a systems approach. The systems approach is a way of solving problems by looking at the problem as a whole and analyzing it systematically. The steps are as follows:

1. Environmental Input in the form of policies, institutions and community views

2. Instrumental Input in the form of methodology, curriculum and modules, SOPs and agreements, teachers, instructors and tutors, facilities and infrastructure 
3. Input in the form of students, parents, teachers or facilitators, organizers, schools and communities

4. Output in the form of a learning community

5. The process is in the form of steps and strategies

Then one step that is quite good for Yogyakarta youth so as not to fall into the practice of early marriage and several other deviant cases is by providing assistance and counseling, mini talk shows and assessing as well as creating a deliberalization room and a sovereign system (learning art room).

\section{MEDIA AS ACTUAL EDUCATION ON THE URGENCY OF PREVENTING EARLY MARRIAGE AND REPRODUCTIVE HEALTH}

The media has an important role in delivering information to the public. The role of the media for millennial society has a complex meaning in some of its applications. Media can also be a means of entertainment or education. Even since the outbreak of the Covid-19 case in the media world, it has become very crucial, especially for those public stakeholders who must provide actual information. Not only that, the media is also a tool for transforming knowledge that is used by event organizers to hold online discussion classes. Therefore, online media has become the most up-to-date tool for exchanging information.

Information such as newspapers, television, radio and several information media have an important role in conveying news to the public about educational, social, health and economic issues. Therefore, it is important to be information literate, this is stated in the Health Law Number 36 Year 2009 Article 7 which explains that everyone has the right to get education and health information in a balanced and responsible manner. Then the sound of this law is strengthened by the Government Regulation of the Republic of Indonesia Number 46 of 2014 concerning Health Information Systems which explains that Health information is a document 
that has been processed and processed to produce information that contains value and meaning to support health development. ${ }^{5}$

The importance of conveying the urgency of early marriage education makes online discussion media an actual means of education-based communication practices. Educational communication is a unique delivery process that has a tendency in the mission of education and education and learning. The message conveyed from educational communication is instructional where this communication practice is specifically designed to bring about behavioral changes towards the target (participant). ${ }^{6}$ From the discussion event organized by PKBI DIY, the author captures the intent and purpose of changing and providing an understanding of the importance of minimizing the practice of early marriage and the impacts of early marriage.

Dwi Ajeng7 said in her research that Aisyiah's media also uses Instagram as an actual educational tool in sharing information about women's reproductive health. The media actualization is of course accompanied by attractive color visualization, easy-to-understand language and coupled with accurate infographics to make the media more informative and interesting. Therefore the importance of communication media as an educational manifesto as a form of awareness of deviant social phenomena that requires a social media as a medium for distributing positive information.

According to Esty Wulandari, ${ }^{8}$ public ignorance about the importance of maintaining reproductive health can endanger their health. Therefore, the media has a role as a strategic tool to convey information related to reproductive health. Negligence in maintaining and paying attention to reproductive health which is still

5 Saleha Rodiah dkk, "Model Diseminasi Informasi Komunikasi Kesehatan Masyarakat Pedesaan di Kabupaten Bandung Barat", Jurnal Kajian Komunikasi, Vol 6, No 2, Desember 2018, p. 176.

6 Yanti Setianti dkk, " Media Informasi Kesehatan Reproduksi Bagi Remaja Disabilitas Tunagrahita di Jawa Barat”, Jurnal Kajian Komunikasi, Vol 7, No 2, Desember 2019, p. 174

7 Dwi Ajeng Widarini, " Pemanfaatan Media Sosial dalam Sosialisasi Kesehatan Reproduksi dan Nutrisi Perempuan”, Jurnal Komunikasi Pembangunan, Vol 17, No 1, Februari 2019 , p.99.

8 Esty Wulandari," Penggunaan Media Komunikasi Visual sebagai Strategi Komunikasi dalam Keseharan Reproduksi Remaja, dalam https://digilib.uns.ac.id, p.10 
considered taboo can trigger an increase in cases of early marriage practices. Based on these two examples, online media has an important role in the transformation of digital information such as reproductive health. So that in one of the discussions held by PKBI DIY, it became an introduction to reproductive health education for adolescents to avoid the practice of early marriage. ${ }^{9}$

The holding of the event was also presented by several public figures whose concentration lies in issues related to reproductive health. Yogyakarta Health Office became one of the resource persons with the main discussion about human reproductive organs and their vulnerabilities and members of the National PKBI talked about the causes and efforts to prevent early marriage by holding small discussions to deliver adolescent reproductive health education. Meanwhile, BKKBN members submitted data on the prevalence of early marriage in Yogyakarta. Therefore, the online discussion media which is being loved by most of the event organizers make it an interactive bridge in conveying the purpose of the event.

\section{CONCLUSION}

Based on the description above, the author concludes that the high cases of early marriage have several factors, even globally, the factors are almost the same throughout the world. These factors include unwanted pregnancies, economics, culture, environmental influences, and so on. Other factors found in this paper, such as the voice of a public figure, which shows the romance of a public marriage to proper things, actually lead to the desire of teenagers who are not ready and have not been categorized as marriageable age forced him to marry. So that the event organized by PKBI DIY became one of the interactive and educative events in the delivery of information on adolescent reproductive health. The effectiveness of online discussion media leads teenagers to understand the importance of adolescent health and efforts to avoid the practice of early marriage.

9 Thohir, Umar Faruq. "Konsep Tawakkal Dalam Perspektif Pasangan Perkawinan Anak di Desa Wedusan Probolinggo Jawa Timur." Jurnal Hukum Islam (2019): 210-229. 
QAULAN, Vol. 2, No.2, Desember 2021

Ainul Luthfia Al Firda, Implementation of System...

\section{REFERENCES}

Fatimah, Siti. Faktor-faktor Pendorong Pernikahan Dini dan Dampaknya di Desa Sarimulya Kecamatan Kemusu Kabupaten Boyolali, Skripsi, Universitas Negeri Semarang, 2009.

Kristina, Astridya Paramita dan Lusi. Tehnik Focus Group Discussion dalam Penelitian Kualitatif, Buletin Penelitian Sistem Kesehatan, Vol 16, No 2, April 2013.

Listiyanto, Tabah. Pengaruh Pemanfaatan Video Edukasi sebagai Media Pembelajaran terhadap Motivasi Belajar Sejarah Siswa Kelas XI/IPS di SMA Negeri 1 Bandar Tahun Ajaran 2014/2015, Skripsi, Universitas Negeri Semarang, 2015.

Rachel, Jessica. Anak Muda Bicara Perkawinan Anak, https://pkbi.or.id/anak-mudabicara-perkawinan-anak/, diakses pada tanggal 12 Januari 2021.

Rayi Lujeng dkk. Kekerasan dalam Rumah Tangga pada Kasus Pernikahan Dini, Jurnal Medula Unila, Vol 6, No 1, 2016.

Saksono, Antonius Jhe. PKBI Mengurai Pergulatan Pernikahan Dini di Jawa Tengah, https://pkbijateng.or.id/pkbi-mengurai-pergulatan-pernikahan-dini-dijateng/, diakses tanggal 12 Januari 2021.

Saleha Rodiah dkk. Model Diseminasi Informasi Komunikasi Kesehatan Masyarakat Pedesaan di Kabupaten Bandung Barat, Jurnal Kajian Komunikasi, Vol 6, No 2, Desember 2018

Tsany, Fitriana. Tren Pernikahan Dini di Kalangan Remaja: Studi Kasus di Kabupaten Gunungkidul Yogyakarta Tahun 2009-2012, Jurnal Ilmiah Sosiologi Agama, Vol 9, No 1, Januari-Juni 2015

Thohir, Umar Faruq. "Konsep Tawakkal Dalam Perspektif Pasangan Perkawinan Anak di Desa Wedusan Probolinggo Jawa Timur." Jurnal Hukum Islam (2019): 210-229.

Widarini, Dwi Ajeng. Pemanfaatan Media Sosial dalam Sosialisasi Kesehatan Reproduksi dan Nutrisi Perempuan, Jurnal Komunikasi Pembangunan, Vol 17, No 1, Februari 2019.

Wulandari,Esty. Penggunaan Media Komunikasi Visual sebagai Strategi Komunikasi dalam Keseharan Reproduksi Remaja, dalam https://digilib.uns.ac.id.

Wuryantoro, Sugeng Puji Leksono dan Mira. Implementasi Teori, Tekhnik, dan Prinsip Pekerjaan Sosial, Malang: Intrans Publishing, 2019.

Yanti Setianti dkk. Media Informasi Kesehatan Reproduksi Bagi Remaja Disabilitas Tunagrahita di Jawa Barat, Jurnal Kajian Komunikasi, Vol 7, No 2, Desember 2019. 